IRA-International Journal of Management \& Social Sciences

ISSN 2455-2267; Vol.13, Issue 01 (October 2018)

Pg. no. 1-9.

Institute of Research Advances

http://research-advances.org/index.php/RAJMSS

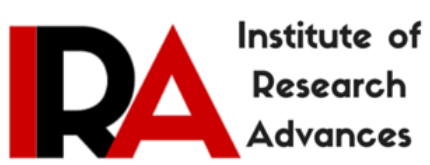

\title{
Reporters Opinion on Managements of Telugu Newspapers: A Survey Analysis in Andhra Pradesh
}

\author{
Dr. J. Madhu Babu, ${ }^{1, \#} \&$ J. Manjunath ${ }^{2}$ \\ ${ }^{1}$ Assistant Professor, Depart of Journalism \& Mass Communication, Acharya Nagarjuna \\ University, Guntur, A.P., India. \\ ${ }^{2}$ Research Scholar, Depart of Journalism \& Mass Communication, Acharya Nagarjuna \\ University, Guntur, A.P., India.
}

\#corresponding author.

Type of Review: Peer Reviewed.

DOl: http://dx.doi.org/10.21013/jmss.v13.n1.p1

How to cite this paper:

Babu, J.M., Manjunath, J. (2018). Reporters Opinion on Managements of Telugu Newspapers: A Survey Analysis in Andhra Pradesh. IRA-International Journal of Management \& Social Sciences (ISSN 2455-2267), 13(1), 1-9. doi:http://dx.doi.org/10.21013/jmss.v13.n1.p1

(C) Institute of Research Advances.

(cc) EY-NC

This work is licensed under a Creative Commons Attribution-Non Commercial 4.0 International License subject to proper citation to the publication source of the work.

Disclaimer: The scholarly papers as reviewed and published by the Institute of Research Advances (IRA) are the views and opinions of their respective authors and are not the views or opinions of the IRA. The IRA disclaims of any harm or loss caused due to the published content to any party.

Institute of Research Advances is an institutional publisher member of Publishers International Linking Association Inc. (PILA-CrossRef), USA. The institute is an institutional signatory to the Budapest Open Access Initiative. Hungary advocating the open access of scientific and scholarly knowledge. The Institute is a registered content provider under Open Access Initiative Protocol for Metadata Harvesting (OAI-PMH).

The journal is indexed \& included in WorldCat Discovery Service (USA), CrossRef Metadata Search (USA), WorldCat (USA), OCLC (USA), Open J-Gate (India), EZB (Germany) Scilit (Switzerland), Airiti (China), Bielefeld Academic Search Engine (BASE) of Bielefeld University, Germany, PKP Index of Simon Fraser University, Canada. 


\begin{abstract}
This study examines the working conditions and occupational stress of Journalists in Telugu news dailies in Andhra Pradesh. The quantitative survey method was adopted for the study. The population consists of 800 rural journalists of Telugu dailies in Andhra Pradesh. The sample size was chosen to be 100 journalists. The entire questionnaires that were randomly distributed to the 100 selected journalists were duly filled and retrieved. The research results showed that, demographic profile of journalists, Qualification in Journalism, working position in the present organization. Majority of journalists feel professional stress and they have no appointment orders. They were said their work was temporarily basis. Finally concluded that the working condition of Journalists is very low and occupational stress is very high. The attitude of managements did not interest to pay salaries to Journalists.
\end{abstract}

Key words: Telugu Press, Journalists, Working Conditions, Occupational Stress, Management attitude.

\title{
Introduction
}

Journalism is an organization established with the purpose of providing information reporting on various incidents that occur in society. With journalism being an organization that constructs and leads proper public opinion for the sake of social development and change, medium such as the press and electronic media and new media belonging to this category.

Journalism is defined as "The job of gathering, writing and disseminating news and views about the society through the means of the mass media" (Ganiyu \& Akinreti, 2011). Journalism is also a form of communication based on asking and answering the questions Who? What? Where? When? How?(Harcup, 2014).

Journalists have to deliver news, and therefore it is their professional destiny to be constantly wrestling against time. It leads to over laden, work stress. Not only does work stress lower job satisfaction but also has a negative effect on quality of life at a personal level. A study released by the National Advertising Benevolent Society (NABS) has revealed that $23 \%$ of workers in the creative and media sector find their working environment overly stressful. One in seven, present works more than 55 hours a week and four in ten, mainly attribute their stress to external sources. Over, 50\% were worried about to said to senior staff they are feeling stressed, in case it's a viewed as a sign of weakness.

\section{Review of Literature}

Journalism is one of the most stressful careers that have to deal with deadlines, busy work environment, tight schedules, extensive travelling, fulfilling the demands of the editors (Sang-young, 2014). The profession is been rated top ten stressful jobs amongst all the professions in the world and faces a shrinking job market (Shapley,2013). A large number of news reporters in Bangladesh had complained that they could not even report fair news by the threats and pressures of employers and effected parties (Azad \& Hussain, 2014). Journalists are often subject to dangerous and life threatening situations and encounter considerable amount of psychological pressure besides other stress. i.e. work overload and job insecurity.

According to World Health Organizations (1948) stress are states of comprehensive physical, mental and social illness in a person. Though, no profession is stress-free. Some degree of strain and anxiety that could result in productivity and satisfaction at work. It may lead to negative results like mental and physical illness if the stress is excessive (Teasdale. 2006). Work- related stress is considered as the foremost cause of a wide range health problem (Kivimaki et. al., 2006). It is strongly connected to staff turnover, absenteeism, poor morality and declining productivity (Noblet \& Lamontagne, 2006). Increasing level of work place stress can lead to serious legal allegation against any employers like compensation claims, disciplinary issues and work place violence. (Brady cited in Babcock, 2009).

A simple universal definition of stress is elusive, as the psychological and physiological and behavioral response of an individual. They perceives there to be an imbalance between the demands placed upon them and their ability to cope with those demands (Michie, 2002). Responses to stress may be emotional behavioral, cognitive or somatic 
(Michie, 2002). Work place stress can occur as a result of negative interactions between the work environment, the nature of the work itself and workers characteristics. The potential for stress to impact adversely on physical health (Lazarus, 1991); irregular schedules and long working hours (Bourbonnais et. al.1999; Spurgeon et.al.1997); Week social support (Bultmann et.al.2002a, Stansfeld et.al. 1999); role ambiguity (Bultmann et.al. 2002b; De Jonge et.al. 1999); conflicting request (de Jonge et.al. 2000); and job insecurity (Bourbonnais et. al.1999, Mc. Donough, 2000); work place stress may also be linked to individual characteristics such as gender (Stansfeld et.al.1999).

\section{Significance of the study}

The study is significant in find out the journalist's perception on newspapers managements, educational and economical background of journalist. The study is significant in highlighting the attitude of Telugu Newspaper management towards their reporters.

\section{Need of the Study}

For different reasons, the Telugu newspaper management exploits the journalists without giving any salary. Although there is no doubt that this issues that influence the journalist's life and profession. It leads to do malpractices by journalists and also it shows bad impression by the society. The researcher finds out the management attitude towards the journalists through this research study. Therefore, the key question at this moment for newspaper management is how should take steps towards comprehensive betterment of journalist.

\section{Research Objectives}

1. To identify the demographic profile of the Telugu language journalists.

2. To find out the working conditions of journalists in their organizations.

3. To analyze the feelings of journalists on work stress.

4. To collect the journalist opinion on the management attitude.

5. To recommend specific interventions to betterment of journalist profession.

\section{Methodology}

\section{Research Design}

The study was designed to address of objectivities of the research. The study is inductive research approach and it is descriptive in nature. The researchers used a survey based research strategy in this research. The methodological choice of the research is quantitative. Survey method is the research design adopted by the researchers. Survey, according to (Nwodu 2006; p.67). "Is a research method, which focuses on a representative sample, derived from the entire population of study".

\section{Research Setting}

The research setting of the study is the district of Krishna in State of Andhra Pradesh. Many newspaper publications such as Eenadu, Sakshi, Andhrajyothi, Andhra Prabha, Andhra Bhoomi, Surya, Prajasakthi, Visalandhra and Vartha are located in the Vijayawada city.

\section{Area of Study}

The study area is concerned with the entire rural Telugu journalists of Krishna district of Andhra Pradesh, India. The choice of this area is as a result of its proximity to the researchers.

\section{Population of Study}

The population of the study according to Ogile (2005, P.53) "involves a group of persons or aggregate items, things the researcher is interested in getting information from the study". Population refers to all cases or individuals that fit a certain specification (Ohaja, 2003). 
Therefore, the population of the study is 800 journalists of Krishna district. The source is the list Accredited of Journalists from District Public Relation Officer (DPRO), and Register of Membership in Vijayawada Press Club.

\section{Sample Size}

Total 100 journalists of 9 Telugu news dailies were interviews with a view to making the study informative. The all respondents were male journalists and most of them were temporary employees.

\section{Instrument of Data Collection}

The survey intervenes to collect required information and data through structured questionnaire. The questionnaire contains19questions such as a closed ended and open ended questions. The researcher used a 3 point and 5 point Likert rating scale to capture the opinion of the respondents about important determinants of professional stress.

\section{Method of Data Collection}

Respondents were randomly selected from said lists and the researcher gathers phone numbers of 135 of Reporters journalist's. Initial contact was by phone call at a time convenient to the journalists after obtaining informed consent. Among 135 journalists only 100 were answered survey correctly. Remaining respondents not answered properly. Only completed questionnaires were accepted.

\section{Limitations of the study}

The study has some limitations too. Major limitation of the study is the scope of the research as the area does not cover all the districts of Andhra Pradesh due to financial constrain of the researchers. The sample size was limited to 100 as the research was supposed to be completed in a limited period. The Demographic data of the respondents, i.e, Age, Gender, Education, Family size, were considered in this study. Others are not considered in the study.

\section{Data Analysis and Results}

Table 1 shows the demographic information. For this research, researchers collected data from members of Vijayawada Press Club. All respondents were male because they were no female Members (reporters). According collected data $39 \%$ respondents are in the age group of 36-45 years, $27 \%$ have age groups $26-30$ years and $19 \%$ were in age group of 46 to 56 years while $14 \%$ respondents were in age group of 56 years above. Approximately $90 \%$ of the respondents were married, $10 \%$ were unmarried.

Majority of respondents (41\%) from Forward Castes followed by Backward Castes (33\%) and Scheduled castes (23\%) and Scheduled Tribes one percent. Two respondents were not interested to claim their castes.

Majority of respondents $48 \%$ have Degree qualification. $24 \%$ respondents were Undergraduates and $20 \%$ were Postgraduates. Only $8 \%$ respondents have Professional degrees.

In the total sample of $100,51 \%$ of the respondent have four members in their family, followed by $22 \%$ have Three members. $16 \%$ have five above members in their families. The rest of $11 \%$ respondents have two members in their families. 
Table -1 Demographic Information

\begin{tabular}{|c|c|c|c|}
\hline S.No & Particulars & Respondents & $\%$ \\
\hline 1 & \multicolumn{3}{|l|}{ Age } \\
\hline & 20-25Years & 1 & 1.0 \\
\hline & $26-35$ & 27 & 27.0 \\
\hline & $36-45$ & 39 & 39.0 \\
\hline & $46-55$ & 19 & 19.0 \\
\hline & 56 Years Above & 14 & 14.0 \\
\hline & Total & 100 & 100.0 \\
\hline \multirow[t]{7}{*}{2} & \multicolumn{3}{|l|}{ Cast } \\
\hline & FC & 41 & 41.0 \\
\hline & $\mathrm{BC}$ & 33 & 33.0 \\
\hline & $\mathrm{SC}$ & 23 & 23.0 \\
\hline & ST & 1 & 1.0 \\
\hline & Others & 2 & 2.0 \\
\hline & Total & 100 & 100.0 \\
\hline \multirow[t]{6}{*}{3} & \multicolumn{3}{|l|}{ Education } \\
\hline & Below Degree & 24 & 24.0 \\
\hline & Degree & 48 & 48.0 \\
\hline & Post-Graduation & 20 & 20.0 \\
\hline & Other Professional Degree & 8 & 8.0 \\
\hline & Total & 100 & 100.0 \\
\hline \multirow[t]{6}{*}{4} & \multicolumn{3}{|l|}{ Members in Family } \\
\hline & Two Members & 11 & 1100 \\
\hline & There Members & 22 & 22.0 \\
\hline & Four members & 51 & 51.0 \\
\hline & Five Above Members & 16 & 16.0 \\
\hline & Total & 100 & 100.0 \\
\hline \multirow[t]{4}{*}{5} & \multicolumn{3}{|l|}{ Marital Status } \\
\hline & Married & 90 & 90.0 \\
\hline & Unmarried & 10 & 10.0 \\
\hline & Total & 100 & 100.0 \\
\hline
\end{tabular}

A study of data in table 2 indicates the working experience in the current organization. Out of the total 100 respondents $51 \%$ of them have bellowed 5 years' experience. Followed by 33\% were 6 to 10 years' and $15 \%$ respondents were 11 to 15 years' experience in the current organization. Interestingly, only one respondent have above 20 years' experience.

The total experience in field of journalism of respondents, (27\%) had been working for 11-15 years as a journalist. Approximately $25 \%$ had been working for 20 years above, $22 \%$ had been working below for $6-10$ years. $15 \%$ had been working below 5 years and $11 \%$ had been working for 16-20 years.

Table -2 Working Experiences of Respondents

\begin{tabular}{|c|l|c|c|}
\hline S.No. & Working Experience in current organization & Respondents & $\%$ \\
\hline 1 & Below 5 years & 51 & 51.0 \\
\hline 2 & 6-10 Years & 33 & 33.0 \\
\hline 3 & $11-15$ years & 15 & 15.0 \\
\hline 4 & $16-20$ Years & - & - \\
\hline 5 & 20 Years above Total & 1 & 1.0 \\
\hline \multicolumn{1}{|c|}{ - } & 100 & 100.0 \\
\hline S. No & Experience in field of journalism & Respondents & 15.0 \\
\hline 1 & Below 5 years & 15 & 22.0 \\
\hline 2 & 6-10 Years & 22 & 27.0 \\
\hline 3 & $11-15$ years & 27 & \\
\hline
\end{tabular}


IRA-International Journal of Management E' Social Sciences

\begin{tabular}{|l|l|c|c|}
\hline 4 & $16-20$ Years & 11 & 11.0 \\
\hline 5 & 20 Years above & 25 & 25.0 \\
\hline \multicolumn{1}{|c|}{ Total } & 100 & 100.0 \\
\hline
\end{tabular}

Statement: Are you receiving monthly salary?

Only $33 \%$ of the respondents received monthly salary. $48 \%$ respondents said 'no', $19 \%$ 'can't say'.

Statement: Does Wage Board Act is followed in your organization?

A very large majority (73\%) respondents said 'no'. Only 3\% said 'yes' and 24\% respondents were said 'can't say'.

Statement: Have you opened PF accounts?

A very large majority (80\%) of respondents said 'no', they were not opened PF accounts. 24\% respondents said 'can't say'. Only 6\% respondents said their newspaper organizations was opened PF accounts.

Statement: The organization force you to do more work?

Nearly half of the (43\%) respondents said neutral opinion 'can't say'. 30\% respondents said 'yes', and $27 \%$ said 'no'.

Statement" Does the organization dictate you in specific news to be written?

$43 \%$ of respondents said 'yes', their organization dictate to write specific news. $47 \%$ respondents said 'no' and 10 $\%$ said natural opinion.

Statement: Does exploitation of labor power happening towards employees?

Only 14\% respondents said 'no' and $62 \%$ said 'yes', their organization exploit the labor power.

Statement: Does your organization monitor you?

$88 \%$ respondents said 'yes'

Statement: Does organization transferred you?

A majority of $78 \%$ respondents said 'no'.

Statement: Did you management thought that remove from the work?

$70 \%$ respondents said 'no'.

Table 3 Respondents opinion on Organization

\begin{tabular}{|c|c|c|c|c|c|}
\hline S. No & Statements & Total & Yes & No & Can't say \\
\hline 1 & Are you receiving monthly salary? & 100 & 33 & 48 & 19 \\
\hline 2 & Dos Wage Board Act is followed in your organization & 100 & 3 & 73 & 24 \\
\hline 3 & Have you opened PF Accounts & 100 & 6 & 80 & 14 \\
\hline 4 & Does the organization force you to do more work & 100 & 30 & 27 & 43 \\
\hline 5 & Does the organization dictate you in specific news to be written & 100 & 43 & 47 & 10 \\
\hline 6 & Does exploitation of labor power happening towards employees & 100 & 62 & 14 & 24 \\
\hline 7 & Does your Organization monitor you & 100 & 88 & 3 & 9 \\
\hline 8 & Does your organization transferred you & 100 & 17 & 78 & 5 \\
\hline 9 & Did your management thought that to remove from the work & 100 & 7 & 70 & 23 \\
\hline
\end{tabular}

Statement: How is the work stress on you?

$17 \%$ respondents said 'It will be more,' $32 \%$ respondents said 'It will be,' $37 \%$ respondents said 'wasn't', $10 \%$ said

'Not at all' and $4 \%$ respondents said 'can't say.

Statement: How are the management attitude in media? 
$29 \%$ respondents said management attitude in media 'change should be done'. $24 \%$ respondents said management attitude is 'its worst'. 23\% said 'never mind' and $21 \%$ said 'almost worst'. Only 3\% of respondents said the answer 'can't say'.

Statement: How the management using worker at work?

Majority of respondents said 'average', followed by $29 \%$ respondents said 'bad/worst', 15\% respondent said 'Too bad/Too worst', 7\% respondents said 'can't say'. But only 9\% respondents said 'Good'. 40\% respondents said 'it's ok'.

Table 4 Respondents Opinion on Working Conditions

\begin{tabular}{|c|c|c|c|}
\hline S.No. & How is the work stress on you? & Respondents & $\%$ \\
\hline 1 & It will be more & 17 & 17.0 \\
\hline 2 & It will be & 32 & 32.0 \\
\hline 3 & Can't say & 4 & 4.0 \\
\hline 4 & Wasn't & 37 & 37.0 \\
\hline 5 & Not at all & 10 & 10.0 \\
\hline \multicolumn{2}{|r|}{ Total } & 100 & 100.0 \\
\hline & \multicolumn{3}{|l|}{ How are the Management attitude in media? } \\
\hline 1 & All most worst & 21 & 21.0 \\
\hline 2 & Its worst & 24 & 24.0 \\
\hline 3 & Can't say & 3 & 3.0 \\
\hline 4 & Never mind & 23 & 23.0 \\
\hline 5 & Change should be done & 29 & 29.0 \\
\hline \multicolumn{2}{|r|}{ 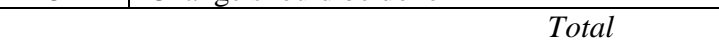 } & 100 & 100.0 \\
\hline & \multicolumn{3}{|l|}{ How the management using worker at work? } \\
\hline 1 & Good & 9 & 9.0 \\
\hline 2 & Its ok & 40 & 40.0 \\
\hline 3 & Can't say & 7 & 7.0 \\
\hline 4 & Bad/worst & 29 & 29.0 \\
\hline 5 & Too bad/worst & 15 & 15.0 \\
\hline \multicolumn{2}{|r|}{ Total } & 100 & 100.0 \\
\hline
\end{tabular}

\section{Summary of Key Findings}

- All respondents were male.

- More than one third of respondents are between 36-45 age group.

- A large majority of respondents are from Forward Castes. Scheduled Tribes representation is very negligible (one in hundred) in Telugu press.

- While $51 \%$ respondents have 4 members in their families.

- $67 \%$ of respondents said they were no salary.

- Only $3 \%$ respondents have a clear idea about on Wage Board Act.

- While $80 \%$ respondents not have any PF accounts.

- $30 \%$ respondents said their managements force to do more work.

- $43 \%$ respondents said their managements dictate in specific news to be written.

- $62 \%$ respondents said their managements exploit the labor power.

- $78 \%$ of respondents said their managements did not transfer their journalists. Similarly $70 \%$ respondents said their management did not remove of their journalists' job. The reason is they can't pay any salary.

- Half of the respondents have below 5 years' experience in current organization.

- $27 \%$ of respondents said they have $11-15$ years' experience in journalism.

- Nearly $50 \%$ of respondents feel stress.

- $29 \%$ respondents think the media management attitude should be change.

- $15 \%$ of respondents said the management using worker at work is too bad. 


\section{Recommendations for Solution of Stress Free}

Some specific stress management interventions like relaxation programs to be organized for the journalists. Most of the research on stress management discussed the success of relaxation programs in combating stress. Relaxation programs may include yearly out-door family events could be organized to keep them charged and stress free. Employee wellbeing program i.e. Recreations facility, family events, family friendly work environment recognition and reward for their wellness.

Press club, the working journalists unions, may take some measures to help the journalists by taking programs like counseling, advocacy program, policy formulation to reduce stress and mainly a unified service rules for the journalists to promote better human resource management practices in this profession.

The Government should undertake protection programs for the journalist by providing job and live security. The journalists killed in the line of duty should be provided with justice and their family members should be taken under governmental rehabilitation program.

\section{Conclusion}

A particular problem in journalism is very little number of reporters comes under this working journalists category, remaining all were stringers or contributories, because the rules was not applicable to these journalists.

The attitude of Press Managements very degrading towards Reporters. So that many young journalists were feel heavy stress. The reporters did not get any job security and their present and future life became a question mark. They are worked for years together in the status of stringers and contributors. Majority of Journalists did not receive any honorarium or contribution / consolidate pay or line account for so many years. The present situation mirrored, the reporters eagerly waiting for an invitations for breakfast and meals from the press meet /program organizers and some other financial gifts (money covers).

Working hours are difficult in to implement in journalistic profession. A field journalist's regular assignment in values carrying out preparations, going to the scene of an event / incident returning to the news room and writing a news item / News story (editing item). Media owners said journalists in their news coverage work, which is sometimes less and sometimes more than the prescribed working hours. Most of the respondents in this survey believe that working hours and over - time work are not a priority problem for journalists. Some respondents said that they have a mutual understanding with the management in this regard.

Journalist unions in Andhra Pradesh should concentrate for supporting journalists to solve the problems by decreasing the level of stress amongst journalists and also the Association must concentrate on resolving Journalists problems than personnel and political interests. Similarly, the management of Newspapers in Andhra Pradesh should provide good salaries to journalists and to provide stress removal environment at work place. The Government also have taken steps to implement the recommendations of the Majithia Wage Board and to protect journalist's rights and lives.

\section{References}

[1]. Azad, A.K., \& Hussain, S. (2015). IBS Journal. Vol. 22, Bangladesh: Institute of Bangladesh Studies.

[2]. Bourbonnais, Renee, Comeau, Monique and Vezina, Michel (1999), "Job strain and evolution of the mental health among nurses", Journal of Occupational Health Psychology. 4(2), pg. 95-107.

[3]. Brady, J (Cited from Babcock, P.) (2009).Work place stress? Deal with it. HR Magazine, May 2009, 67.

[4]. Bultmann, UTE, Kant, Ijmert, Kasl et. al. (2002a) "Lifestyle factors as risk factors for fatigue and psychological distress in the working populations: prospective results from the Maastricht Cohort Study", Journal of Occupational and Environmental Medicine. 44 (2), pp. 116-124.

[5]. Bultmann, UTE, Kant, Ijmert, Schroer, Kees and Kasl Stanislay (2002b) "The relationship between psychological work characteristics and fatigue and psychological distress". International Archives of Occupational and Environmental Health. 75(4), pp. 259-266.

[6]. De Jonge, Jan, Mulder, Marihe and Nijhuis, Frans (1999) "The incorporation of different demand concepts in the job demand- control model; Effects on Healthcare Professionals". Social Science and Medicine. 48 (9), pp.1149-1160. 
[7]. De Jonge, Jan, Reuvers Marielle, Houtman, Irene, Bongers, Paulien and Kompier, Michiel (2000) "Linear and nonlinear relations between psychological job characteristics, subjective outcomes, and sickness absence baseline results from SMASH. Study on musculoskeletal disorders, absenteeism, stress and health" Journal of Occupational Healthy Psychology. 5, pp.256-268.

[8]. Ganiyu, M., \& Akinreti, Q. (2011) Secrets of Online and Multimedia Journalism: A Manual for Online and Multimedia Journalism Practice in Africa. Ibadan Emgee Publishers Ltd.

[9]. Harcup, T. (2014). Journalism: Principles and Practice ( $2^{\text {nd }}$ Edition). London: SAGE Publication Ltd.

[10].Kivimaki, M., Virtanen, M., \& Elovainio, M. (2006). Work Stress in the Etiology of Coronary Heart Disease- A MetaAnalysis. Scandinavian Journal of work, Environment and Health. 32,431-442.http://dx.doi.org/10.5271/sjweh.1049.

[11].Lszarus, Richard (1991) "Psychological stress in the work place", in: P.L. Perrewe (Ed), Hand Book on Job Stress, Corte Madera, CA: Select Press, pp.1-13.

[12].Mcdonough,Peggy (2000) “Job insecurity and health”. International Journal of Health service. 30 (3), pp. 453-76.

[13]. Michie, Susan (2002) "Causes and Management of stress at work" Occupational and Environmental Medicine 59,pp. 67-72.

[14].Noblet, A.,\& Lamontagne, A.D.(2006). The Role of Work Place Health Promotion In Addressing Job Stress. Health Promotion International, 21, pp346-353.http://dx.doi.org/10.1093/heapro/dal029.

[15].Nwodu, L.C. (2006). Research in Communication and other Behavioral Sciences: Principles, Methods, and Issues. Enugu: Rhyce Kerex. Publishers.

[16].Ogili, E.E, (2005). Project Writing: Research Best Practice. Enugu: Providence press Nigeria Ltd.

[17]. Ohaja, E. (2003). Mass Communication Research and Project Report Writing. Lagos: John Letterman Ltd.

[18].Shapley, L. (2013).Most stressful jobs: Journalism Careers make 2013 List. The Denver Post, 16,

[19].April, 2013. http://blogs.denverpost.com/editors/2013/04/16media- jobs- make-list- of -to-stress full-careers-of $2013 / 857 /$.

[20].Sang-young, P., \& Cho,S,(2014).Effects Of Journalist's Job Stress Factors on Physical Conditions. Advanced Science and Technology Letters, 72, 11-15.

[21].Spurgeon. A, Harrington, J.M. \& Cooper, C.L. (1997). "Health and safety problems associated with long working hours: a review of the current position" Occupational and Environmental Medicine, 54 (6) pp. 367-75.

[22].Stansfeld, S.A., Fuhrer, R., Shipley M.J. \& Marmot, M.G. (1999). "Work characteristics predict psychiatric disorder; prospective results from the Whitehall II study", Occupational and Environmental Medicine. 56 (5), pp.302-7.

[23].Teasdale, E.L. (2006). Work place stress, Psychiatry. 5, pp. 251-254. http://dx.doi.org/10.1053/j.mppsy.206.04.006. 